\title{
Constitutive Activation of Signal Transducers and Activators of Transcription 3 Correlates with Better Prognosis, Cell Proliferation and Hypoxia-Inducible Factor-1 $\alpha$ in Human Gastric Cancer
}

\author{
Sungmin Woo ${ }^{a}$ Byung Lan Lee ${ }^{a, d, e}$ Jiyeon Yoon ${ }^{a}$ Sung Jin Cho ${ }^{f}$ \\ Tai-Kyoung Baik ${ }^{f}$ Mee Soo Chang ${ }^{b}$ Hee Eun Lee ${ }^{b}$ Jong-Wan Park ${ }^{c, e}$ \\ Young-Hoon Kim ${ }^{g}$ Woo Ho Kim ${ }^{\text {b, d }}$ \\ Departments of a Anatomy, b Pathology, ${ }^{\mathrm{c} P h a r m a c o l o g y,}{ }^{\mathrm{d}}$ Cancer Research Institute and ${ }^{\mathrm{e}}$ Ischemic/Hypoxic Disease \\ Institute, Medical Research Center, Seoul National University College of Medicine, Seoul, fDepartment of Anatomy and \\ Neurosciences, Eulji University School of Medicine, Daejon, and 9 Inha University College of Medicine, Incheon, Korea
}

\section{Key Words}

Signal transducers and activators of transcription 3 .

Stomach cancer • Tissue array • Immunohistochemistry •

Hypoxia-inducible factor- $1 \alpha$

\begin{abstract}
Objective: We aimed to investigate the biological significance of signal transducers and activators of transcription 3 (STAT3) in gastric carcinoma. Methods: Immunohistochemistry was performed on tissue array slides containing 285 gastric carcinoma specimens. The relationship between the nuclear expression of phospho-Tyr705-STAT3 (pSTAT3), an active form of STAT3, and prognosis, clinicopathological factors, proliferation, cell cycle regulators, apoptosis regulators, or angiogenesis-related proteins was evaluated. Results: In nonneoplastic gastric mucosa, pSTAT3 was observed primarily in the nuclei of cells in the proliferative zone and intestinal metaplasia. In gastric carcinomas, nuclear STAT3 activation was observed in $36 \%$ of cases and was positively correlated with the Ki-67 labeling index and earlier tumor stage, whereas it was inversely correlated with lymphatic metastasis and distant metastasis $(p<0.05)$. Moreover, survival analyses
\end{abstract}

showed that PSTAT3 expression was an independent prognostic factor of good survival. In addition, the expression of nuclear PSTAT3 positively correlated with that of cyclin D1, p21, p27, hypoxia-inducible factor- $1 \alpha$, or vascular endothelial growth factor $(p<0.05)$. Conclusions: STAT3 activation is an early event in gastric tumorigenesis and significantly correlates with better prognosis, proliferation and angiogenesis. Thus, STAT3 activation may be a valuable prognostic variable and therapeutic target in gastric carcinoma.

Copyright $\odot 2011$ S. Karger AG, Basel

\section{Introduction}

Signal transducers and activators of transcription (STAT) is a family of proteins that are transducers and transcription factors. They are activated by phosphorylation on tyrosine residue in the cytoplasm, after which they translocate into the nucleus to regulate gene expression [1-3]. Among STAT family members, STAT3 is of

S. Woo and B.L. Lee contributed equally to this paper.

\section{KARGER}

Fax +4161306 1234

E-Mail karger@karger.ch

www.karger.com (c) $2011 \mathrm{~S}$. Karger AG, Basel

1015-2008/11/0786-0295\$38.00/0

Accessible online at:

www.karger.com/pat
Woo Ho Kim, MD, PhD

Department of Pathology

Seoul National University College of Medicine

28 Yongon-dong, Chongno-gu, Seoul 110-799 (Korea)

Tel. +82 2740 8269, E-Mail woohokim@ snu.ac.kr 
particular interest due to its constitutive phosphorylation in a large proportion of human cancers and its ability to induce neoplastic transformation [4].

Constitutively active STAT3 has been demonstrated in various cancer cells [5-8], animal models [9] and human cancer tissue specimens [6, 10-13]. In ovarian, breast and prostate cancer cell lines $[5,6]$, STAT3 activation was shown to be critical for growth and survival. In clinical samples, constitutive activation of STAT3 positively correlated with a poor prognosis for patients with prostate cancer [6], serous ovarian cancer [10], or breast cancer [11]. In contrast, constitutive activation of STAT3 showed a positive association with a good prognosis for patients with head and neck cancer [12] or oral squamous cell cancers [13]. Thus, the prognostic significance of STAT3 may differ according to the cancer cell type.

Gastric cancer remains one of the most frequently diagnosed malignancies worldwide and the major cause of cancer-related death in Asian countries [14, 15], but the underlying molecular mechanisms of its initiation and progression are largely unknown. Regarding the role of STAT3 in gastric cancer, the clinical value of STAT3 activation has been inconsistent $[3,16,17]$. Earlier studies showed that STAT3 activation correlated with the poor prognosis for gastric cancer patients [16, 17]. In contrast, in another study, no significant correlation between them was noted [3]. Furthermore, the intracellular signaling events related to the role of STAT3 in gastric cancer have not been well established. Thus, it is difficult, on the basis of the results reported so far, to comprehensively explain the biological significance of activated STAT3 in the pathogenesis of gastric cancer.

In this study, we evaluated the expression status and the prognostic significance of nuclear phospho-Tyr705STAT3 (pSTAT3), an active form of STAT3, in 285 surgically excised human gastric carcinoma tissues using tissue array slides. We then analyzed the correlations between STAT3 activation and clinicopathological factors, proliferation, cell cycle regulators, apoptosis regulators, or angiogenesis-related proteins.

\section{Patients and Methods}

\section{Patients and Samples}

The files of 285 surgically resected gastric cancer cases examined at the Department of Pathology, Seoul National University College of Medicine, from January 1 to June 30, 1995, were analyzed. Age, sex, tumor location and pTNM stage were evaluated by reviewing the medical records and pathological reports. The mean age of the patients was 54.4 years, and $93 \%$ of the patients had undergone curative resection. The cases enrolled in this study included 205 advanced and 80 early gastric carcinomas. According to the UICC (Union Internationale Contre le Cancer) criteria (6th edition), there were 115 cases in stage I, 53 cases in stage II, 70 cases in stage III and 47 cases in stage IV. No patient had received preoperative chemotherapy or radiotherapy. Glass slides were reviewed to determine histological type according to the WHO and Lauren classification. This series included 109 intestinal, 171 diffuse and 5 mixed types. Clinical outcomes were followed from the date of surgery to either the date of death or December 1,2000 , resulting in a follow-up period ranging from 1 to 72 months (mean 51 months). Cases lost to follow-up and those resulting in death from any cause other than gastric cancer were censored for the survival rate analysis. This protocol was reviewed and approved by the Institutional Review Board of the Seoul National University (Approval No. C-0603-162-170).

\section{Tissue Array Methods}

Six tissue array blocks containing a total of 285 tissue cores obtained from patients with gastric cancer were prepared as described in a previous study (Superbiochips Laboratories, Seoul, Korea) [18]. Briefly, core tissue biopsies (2 $\mathrm{mm}$ in diameter) were taken from individual paraffin-embedded gastric tumors (donor blocks) and arranged in the new recipient paraffin blocks (tissue array blocks) using a trephine apparatus. As we have previously reported [18], the staining results of the different intratumoral areas of gastric carcinomas in these tissue array blocks showed an excellent agreement. A core was chosen from each case for analysis. A tumor occupying more than $10 \%$ of the core area was defined as an adequate case. Each block contained internal controls consisting of nonneoplastic gastric mucosa from the body, antrum and other areas showing intestinal metaplasia. Sections of $4 \mu \mathrm{m}$ thickness were cut from each tissue array block, deparaffinized and dehydrated.

\section{Immunohistochemistry}

Immunohistochemical staining was done using a streptavidin peroxidase procedure [19] after an autoclave-based antigen retrieval process. The list of the antibodies used for immunostaining is summarized in table 1. For pSTAT3, strong nuclear immunoreactivity in $1 \%$ of the tumor cells was considered positive. For hypoxia-inducible factor (HIF)- $1 \alpha$, nuclear staining in $5 \%$ of the tumor cells was considered positive. For Ki-67 staining, we evaluated 300 cells and counted these with nuclear staining of each specimen. The proliferation index was defined as follows: proliferation index $(\%)=100 \times \mathrm{Ki}$-67-positive tumor cells/total tumor cells. For the rest of the antibodies, immunoreactivity in $10 \%$ of the tumor cells was considered positive.

\section{Statistical Analysis}

All statistical analyses were conducted using SPSS version 12.0 software (SPSS, Chicago, Ill., USA). The relationship between nuclear PSTAT3 expression and the cell proliferation was analyzed using the two-tailed Student $t$ test. To determine the significance of correlation between the nuclear expression of PSTAT3 and the clinicopathological factors or the expression of other proteins, either the $\chi^{2}$ test or the Fisher exact test (2-sided) was performed. Survival curves were estimated using the Kaplan-Meier product limit method, and the significance of differences between the survival curves was determined using the log-rank test. To determine 
Table 1. Profiles of antibodies used for immunohistochemistry

\begin{tabular}{|c|c|c|}
\hline Antibody & Dilution & Source \\
\hline pSTAT3 (Tyr705) & $1: 50$ & Cell Signaling Technology, Beverly, Mass., USA \\
\hline $\mathrm{Ki}-67$ & $1: 50$ & DAKO, Carpinteria, Calif., USA \\
\hline Cyclin D1 & $1: 500$ & Santa Cruz Biotechnology, Santa Cruz, Calif., USA \\
\hline Cyclin E & $1: 100$ & Santa Cruz Biotechnology, Santa Cruz, Calif., USA \\
\hline $\mathrm{pRb}$ & $1: 50$ & PharMingen, San Diego, Calif., USA \\
\hline $\mathrm{p} 16^{\mathrm{INK} 4 \mathrm{~A}}$ & $1: 50$ & PharMingen, San Diego, Calif., USA \\
\hline $\mathrm{p} 21^{\text {Waf1/Cip } 1}$ & $1: 100$ & Santa Cruz Biotechnology, Santa Cruz, Calif., USA \\
\hline p27 $7^{\text {KipI1 }}$ & $1: 100$ & Oncogene, Cambridge, Mass., USA \\
\hline p53 & $1: 100$ & DAKO, Carpinteria, Calif., USA \\
\hline $\mathrm{Bcl}-2$ & $1: 100$ & DAKO, Carpinteria, Calif., USA \\
\hline XIAP & $1: 50$ & BD Bioscience, Franklin Lakes, N.J., USA \\
\hline Survivin & $1: 200$ & Santa Cruz Biotechnology, Santa Cruz, Calif., USA \\
\hline pAKT1 & $1: 50$ & New England Biolabs, Beverly, Mass., USA \\
\hline NF- $\kappa \mathrm{B} /$ RelA & $1: 50$ & Santa Cruz Biotechnology, Santa Cruz, Calif., USA \\
\hline c-erbB2 & $1: 75$ & DAKO, Carpinteria, Calif., USA \\
\hline$\beta$-Catenin & $1: 750$ & BD Biosciences, San Jose, Calif., USA \\
\hline VEGF & $1: 200$ & Santa Cruz Biotechnology, Santa Cruz, Calif., USA \\
\hline HIF- $1 \alpha$ & $1: 50$ & J.W. Park, Seoul National University, Seoul, Korea \\
\hline
\end{tabular}

whether the expression of PSTAT3 is an independent prognostic variable, multivariate survival analysis was performed using the Cox proportional hazard model. The results were considered statistically significant when $\mathrm{p}$ values were $<0.05$.

\section{Results}

The Expression of Nuclear pSTAT3 and Ki-67 in Gastric Cancers

In nonneoplastic gastric mucosa, nuclear pSTAT3 was expressed throughout the proliferative zone of the gastric glands (fig. 1a) and in the areas with intestinal metaplasia (fig. 1b). Tumor cells showed pSTAT3 staining mainly in the nucleus (fig. 1c) and sometimes very weakly in the cytoplasm (fig. 1d). Immunohistochemistry for Ki-67 showed nuclear immunoreactivity in proliferative cancer cells (fig. 1e).

\section{Association between Nuclear STAT3 Activation and Clinicopathological Factors}

Data representing the correlation between the expression of nuclear pSTAT3 and the clinicopathological features of the 285 gastric cancer cases are summarized in table 2. Nuclear expression of pSTAT3 was found in $36 \%$ of tumors and was more likely to be found in patients younger than $65(\mathrm{p}=0.026)$ and in earlier-stage tumors $(p=0.001)$. About half of the stage I tumors were nuclear
pSTAT3 positive, while only $27.1 \%$ of stage II, III and IV tumors were positive. Moreover, we found an inverse correlation between the nuclear expression of pSTAT3 and lymph node metastasis $(\mathrm{p}=0.009)$ or distant metastasis $(\mathrm{p}=0.010)$. No association was found between STAT3 activation and gender, tumor location, or lymphatic invasion.

\section{Activation of STAT3 in Relation to Prognosis}

Of the 285 patients, we were able to analyze the correlation between the nuclear expression of pSTAT3 and the prognosis for 280 patients (the data of 5 patients regarding survival duration following surgery was missing). Of the patients analyzed, those with the nuclear expression of pSTAT3 (101 cases) showed a significantly better survival rate than those without its expression $(\mathrm{p}=$ 0.001; fig. 2). Moreover, multivariate Cox regression analysis including the pTNM stage revealed that the expression of pSTAT3 was an independent prognostic factor $(\mathrm{p}=0.027)$.

\section{Association between Nuclear STAT3 Activation and Expression of Other Proteins}

The results of the immunohistochemistry for Ki-67 are summarized in table 3 . The percentages of Ki-67-positive cells were variable. Nuclear expression of pSTAT3 had a significant correlation with the proliferation index $(\mathrm{p}=0.004)$. 

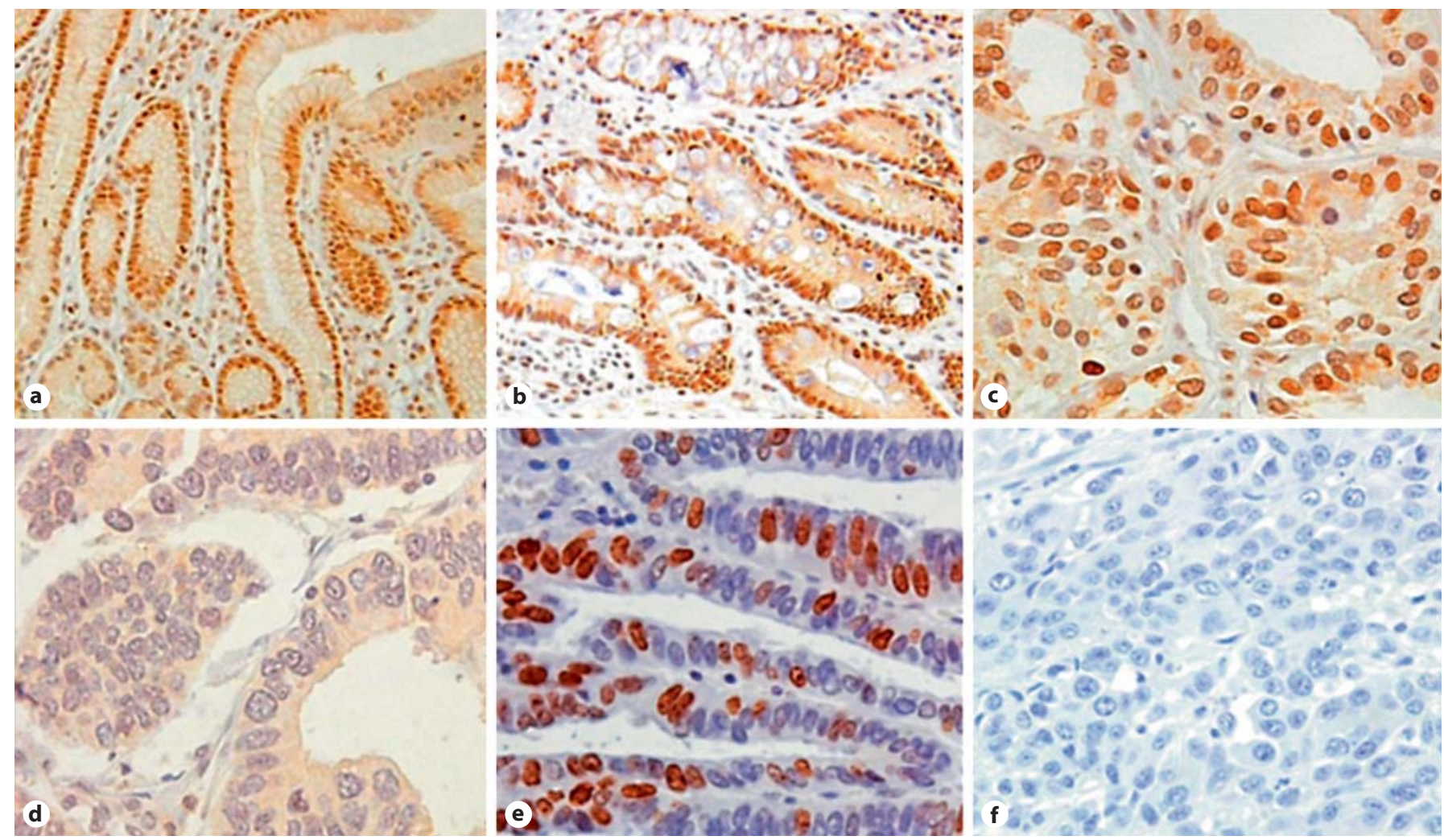

Fig. 1. Representative immunohistochemical feature of the gastric mucosa and cancer. Nuclear pSTAT3 was expressed in the proliferative zone in normal gastric mucosa (a) and in areas of intestinal metaplasia (b) (×200). c Gastric carcinoma cells showing nuclear
pSTAT3 expression $(\times 400)$. d Gastric carcinoma cells without nuclear pSTAT3 expression $(\times 400)$. e Gastric carcinoma cells showing Ki-67 expression in the nucleus $(\times 400)$. $f$ A negative control treated without primary antibodies $(\times 400)$.

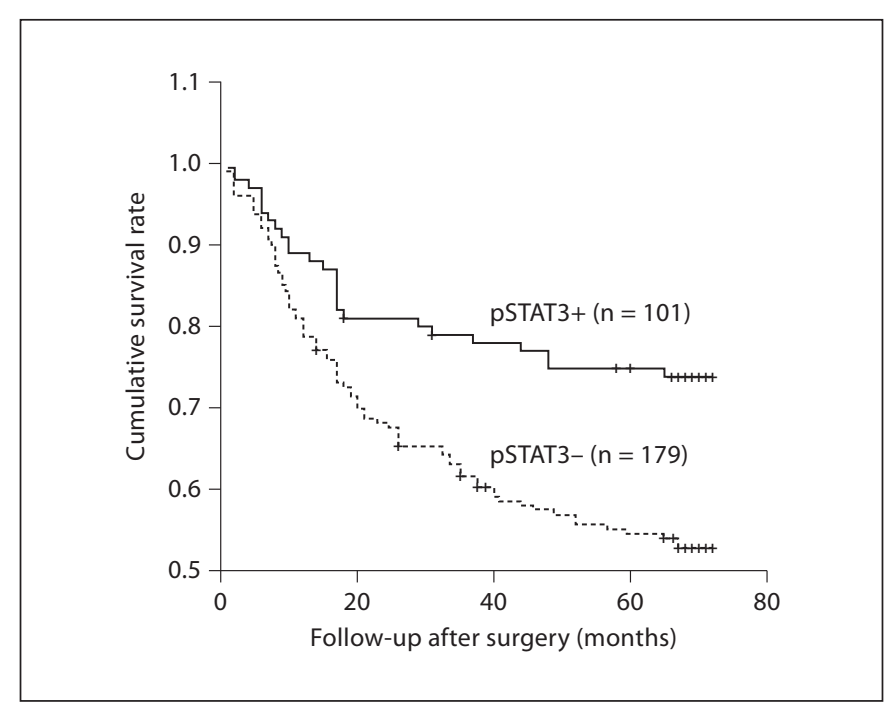

Fig. 2. Kaplan-Meier curves for patient survival. pSTAT3-positive carcinomas (solid line) showed a more favorable prognosis than pSTAT3-negative carcinomas (broken line). $\mathrm{p}=0.001$.
Table 4 shows the correlation between nuclear STAT3 activation and cell cycle regulators. The expression of nuclear $\mathrm{PSTAT} 3$ positively correlated with that of cyclin D1 $(\mathrm{p}=0.025), \mathrm{p} 21^{\text {Waf1/Cip1 }}$ (p21; $\left.\mathrm{p}=0.011\right)$, or $\mathrm{p} 27^{\mathrm{Kip} 1}$ ( $\mathrm{p} 27$; $\mathrm{p}=0.005)$. However, no association was found between the expression of nuclear pSTAT3 and that of cyclin E, retinoblastoma protein $(\mathrm{pRb}), \mathrm{p} 16^{\mathrm{INK} 4 \mathrm{~A}}(\mathrm{p} 16)$, or $\mathrm{p} 53$. In addition, there was no association between the expression of pSTAT3 and that of apoptosis regulator Bcl-2 $(\mathrm{p}=0.858), \mathrm{X}$-linked inhibitor of apoptosis protein (XIAP; $\mathrm{p}=0.646)$, or survivin $(\mathrm{p}=0.423)$.

Previous studies showed that STAT3 activation positively correlated with the AKT1/nuclear factor $\kappa \mathrm{B}$ (NF$\kappa \mathrm{B})$ signaling pathway in colon cancer and head and neck squamous cell cancer $[20,21]$ or with $\beta$-catenin in esophageal squamous cell cancer [22]. In this study, the expression of nuclear pSTAT3 was not correlated with pAKT1 $(\mathrm{p}=0.299)$, NF- $\kappa \mathrm{B}(\mathrm{p}=0.180)$, nuclear $\beta$-catenin $(\mathrm{p}=$ $0.763)$, or $\mathrm{c}$-erbB2 $(\mathrm{p}=0.887)$. 
Table 2. Correlation between the expression of nuclear pSTAT3 and clinicopathological factors

\begin{tabular}{|c|c|c|c|}
\hline & \multicolumn{2}{|l|}{ pSTAT3 } & \multirow[t]{2}{*}{$\mathrm{p}$ value } \\
\hline & nuclear & $\begin{array}{l}\text { negative or } \\
\text { cytoplasmic }\end{array}$ & \\
\hline Total & $103(36)$ & $182(64)$ & \\
\hline \multicolumn{4}{|l|}{ Age } \\
\hline $0-65$ years & $89(39)$ & $137(61)$ & \multirow[t]{2}{*}{$0.026^{\mathrm{a}}$} \\
\hline $66-99$ years & $14(24)$ & $45(76)$ & \\
\hline \multicolumn{4}{|l|}{ Gender } \\
\hline Male & $67(35)$ & $126(65)$ & \multirow[t]{2}{*}{0.468} \\
\hline Female & $36(39)$ & $56(61)$ & \\
\hline \multicolumn{4}{|l|}{ Location } \\
\hline Antrum & $52(34)$ & $102(66)$ & \multirow[t]{2}{*}{0.366} \\
\hline Body and cardia & $51(40)$ & $80(60)$ & \\
\hline \multicolumn{4}{|l|}{ TNM stage } \\
\hline I & $57(50)$ & $58(50)$ & \multirow[t]{4}{*}{$0.001^{\mathrm{a}}$} \\
\hline II & $18(34)$ & $35(66)$ & \\
\hline III & $15(21)$ & $55(79)$ & \\
\hline IV & $13(28)$ & $34(72)$ & \\
\hline \multicolumn{4}{|l|}{ Lymphatic invasion } \\
\hline Absent & $74(37)$ & $125(63)$ & \multirow[t]{2}{*}{0.576} \\
\hline Present & $29(34)$ & $57(66)$ & \\
\hline \multicolumn{4}{|c|}{ Lymph node metastasis } \\
\hline Absent & $47(46)$ & $55(54)$ & \multirow[t]{2}{*}{$0.009^{\mathrm{a}}$} \\
\hline Present & $56(31)$ & $127(69)$ & \\
\hline \multicolumn{4}{|l|}{ Distant metastasis } \\
\hline Absent & $102(38)$ & $167(62)$ & \multirow[t]{2}{*}{$0.010^{\mathrm{a}}$} \\
\hline Present & $1(6)$ & $15(94)$ & \\
\hline
\end{tabular}

Figures in parentheses are percentages.

${ }^{a}$ Considered to be statistically significant.

Table 3. Correlation between the nuclear expressions of pSTAT3 and $\mathrm{Ki}-67$

\begin{tabular}{llll}
\hline & pSTAT3 (nuclear) & p value \\
positive $(\mathrm{n}=230)$ & negative $(\mathrm{n}=42)$ & \\
\hline Ki-67 & $30.61 \pm 21.81$ & $17.31 \pm 17.20$ & $0.004^{\mathrm{a}}$ \\
\hline${ }^{\mathrm{a}}$ Considered to be statistically significant. & \\
\hline
\end{tabular}

Table 5 shows the correlation between nuclear expression of pSTAT3 and angiogenesis-related proteins. The expression of PSTAT3 positively correlated with that of HIF- $1 \alpha(p=0.002)$ as well as that of vascular endothelial growth factor (VEGF; $\mathrm{p}<0.001$ ).
Table 4. Correlation between the expression of PSTAT3 and that of cell cycle regulators

\begin{tabular}{|c|c|c|c|}
\hline & \multicolumn{2}{|l|}{ pSTAT3 } & \multirow[t]{2}{*}{$\mathrm{p}$ value } \\
\hline & nuclear & $\begin{array}{l}\text { negative or } \\
\text { cytoplasmic }\end{array}$ & \\
\hline \multicolumn{4}{|l|}{ Cyclin D1 } \\
\hline Positive & $28(48)$ & $30(52)$ & $0.025^{\mathrm{a}}$ \\
\hline Negative & $68(32)$ & $142(68)$ & \\
\hline \multicolumn{4}{|l|}{ Cyclin E } \\
\hline Positive & $15(42)$ & $21(58)$ & 0.471 \\
\hline Negative & $74(35)$ & $135(65)$ & \\
\hline \multicolumn{4}{|l|}{$\mathrm{pRb}$} \\
\hline Positive & $95(36)$ & $169(64)$ & 0.231 \\
\hline Negative & $5(56)$ & $4(44)$ & \\
\hline \multicolumn{4}{|l|}{$\mathrm{p} 16^{\mathrm{INK} 4 \mathrm{~A}}$} \\
\hline Positive & $68(37)$ & $117(63)$ & 0.716 \\
\hline Negative & $30(34)$ & $57(66)$ & \\
\hline \multicolumn{4}{|l|}{$\mathrm{p} 21^{\text {Waf1/Cip1 }}$} \\
\hline Positive & $36(48)$ & $39(52)$ & $0.011^{\mathrm{a}}$ \\
\hline $\begin{array}{l}\text { Negative } \\
\text { p2 } 27^{\text {Kip1 }}\end{array}$ & $60(31)$ & $131(69)$ & \\
\hline Positive & $33(52)$ & $30(48)$ & $0.005^{\mathrm{a}}$ \\
\hline Negative & $60(32)$ & $125(68)$ & \\
\hline \multicolumn{4}{|l|}{ p53 } \\
\hline Positive & $39(39)$ & $62(61)$ & 0.640 \\
\hline Negative & $63(36)$ & $113(64)$ & \\
\hline
\end{tabular}

Figures in parentheses are percentages.

${ }^{a}$ Considered to be statistically significant.

\section{Discussion}

Since previous reports on the implication of STAT3 activation in gastric carcinoma have been inconsistent [3, $16,17]$, this study obtained gastric cancer specimens from a large consecutive series of gastric cancer patients from a single referral center, all of whom had been treated using similar surgical and adjuvant chemotherapy regimens. We then extended previous studies and found a positive correlation between STAT3 activation and clinicopathological factors, better prognosis, proliferation and angiogenesis.

Dysregulation of cellular proliferation is a prominent feature of all cancers. In this study, nuclear pSTAT3 expression in the nonneoplastic gastric mucosa was mainly observed in the proliferative zone of normal gastric glands and in the areas of intestinal metaplasia. Because the intestinal metaplasia shows a higher proliferation in- 
Table 5. Correlation between the expression of pSTAT3 and that of angiogenesis-related proteins

\begin{tabular}{llcl}
\hline & pSTAT3 & p value \\
\cline { 2 - 3 } & nuclear & $\begin{array}{c}\text { negative or } \\
\text { cytoplasmic }\end{array}$ & \\
\hline HIF-1 $\alpha$ & $35(49)$ & $37(51)$ & $0.002^{\mathrm{a}}$ \\
$\quad$ Positive & $50(28)$ & $128(72)$ & \\
$\quad \begin{array}{l}\text { Negative } \\
\text { VEGF }\end{array}$ & & & \\
$\begin{array}{l}\text { Positive } \\
\text { Negative }\end{array}$ & $52(53)$ & $46(47)$ & $<0.001^{\mathrm{a}}$ \\
\hline
\end{tabular}

Figures in parentheses are percentages.

${ }^{a}$ Considered to be statistically significant.

dex than the normal gastric mucosa [23-25], this expression pattern suggests a positive association between pSTAT3 expression and cell proliferation. Moreover, STAT3 activation in gastric carcinoma was positively correlated with the proliferation index evaluated by Ki-67 labeling $(p=0.004)$. Thus, our results indicate that STAT3 activation, at least in part, is associated with cell proliferation in human gastric carcinomas.

In this study, we found that nuclear STAT activation was observed in $36 \%$ of gastric carcinomas and was positively correlated with earlier tumor stage, whereas it was inversely correlated with lymphatic metastasis $(\mathrm{p}=0.009)$ and distant metastasis $(\mathrm{p}=0.010)$. Moreover, survival analyses showed that pSTAT3 expression was an independent prognostic factor of good survival $(\mathrm{p}=0.027)$. Although similar results were previously shown in head and neck cancer [12] and in oral squamous cell cancer [13], the prognostic implication of STAT3 activation shown in this study is inconsistent with that of earlier studies on gastric cancer $[3,16,17]$. We speculate that this discrepancy, at least in part, stems from differences in the numbers of tumor cases analyzed or antibody used. Previous studies investigated the prognostic significance of STAT3 in a smaller number of human gastric cancer specimens than those used in our study, or performed immunohistochemistry using an antibody against total STAT3, instead of the active form of STAT3 [17]. In addition, discrepancies might have occurred due to interpatient diversity in tumor biology, which causes tumors with similar clinical or pathological characteristics to show a different clinical outcome.
We determined the associations between the expression of nuclear PSTAT3 and that of several key proteins regulating $\mathrm{G}_{1}$-S-phase progression. We found that STAT activation was correlated with the expression of cyclin $D 1(p=0.025)$, known to be a critical regulator of $\mathrm{G}_{1}-\mathrm{S}$ phase transition in cell cycle [26]. Our study also showed a positive correlation between the expression of nuclear pSTAT3 and that of CDK inhibitors p21 ( $\mathrm{p}=0.011)$ or p27 $(\mathrm{p}=0.005)$. Although this result may seem to be paradoxical because p21 and p27 are known to inhibit cyclin D1, our previous study showed that p21, p27 and cyclin D1 positively correlated with each other as well as with the proliferation index evaluated by Ki-67 labeling [26]. In contrast, there was no correlation between STAT3 activation and the expression of cyclin E, pRb, p16, or p53.

Angiogenesis is an important aspect of the growth of solid tumors, including gastric cancer. Earlier studies found that STAT3 activation was positively correlated with VEGF expression as well as microvessel density in gastric cancer $[16,27,28]$. However, there has been no report on STAT3 activation in relation to HIF- $1 \alpha$, although HIF-1 $\alpha$ induces angiogenesis in gastric tumors [29]. In this study, we found a positive correlation between the activations of nuclear STAT3 and HIF- $1 \alpha(\mathrm{p}=0.002)$ as well as VEGF expression ( $\mathrm{p}<0.001)$. Our results suggest that the interaction of these transcription factors may contribute to gastric tumor angiogenesis. This speculation is substantiated by previous findings that VEGF and HIF-1 $\alpha$ expressions were higher in the earlier stages of gastric cancer [30].

In gastric cancer, Choi et al. [3] found that the expression of apoptotic regulatory protein $\mathrm{Bcl}-2$ was higher in STAT3-positive gastric carcinomas, although Bcl-2 expression did not influence overall survival. Inconsistent with this, our study showed that STAT3 activation was not correlated with apoptosis factors, including p53, Bcl2, XIAP and survivin. Our results agree with those of a previous study [13], which showed that STAT3 activation was an early event in head and neck carcinogenesis, although its role in blocking the apoptosis in vivo was not observed.

In conclusion, our data show that nuclear STAT3 activation is one of the early events in gastric carcinogenesis and is an independent prognostic factor of good survival. In addition, STAT3 activation was significantly positively correlated with cell proliferation, cell cycle regulators (cyclin D1, p21 and p27) and angiogenesis-related proteins (HIF-1 $\alpha$ and VEGF), but not with apoptosis-related proteins (p53, Bcl-2, XIAP and survivin). Al- 
though further investigations are needed to clarify the molecular mechanisms involved in STAT3 activation, these findings suggest that STAT3 is a valuable biomarker and therapeutic target in early-stage gastric carcinomas.

\section{Acknowledgements}

This study was supported by a grant from the National R\&D Program for Cancer Control, Ministry for Health and Welfare, Republic of Korea (101146). J. Yoon was supported by the second stage of the Brain Korea 21 Project in 2008. The authors thank Superbiochips (Korea) for tissue array slides.

\section{References}

1 Bromberg JF, Wrzeszczynska MH, Devgan G, Zhao Y, Pestell RG, Albanese C, Darnell JE Jr: Stat3 as an oncogene. Cell 1999;98:295-303.

- Frank DA: STAT signaling in the pathogenesis and treatment of cancer. Mol Med 1999; 5:432-456.

-3 Choi JH, Ahn MJ, Park CK, Han HX, Kwon SJ, Lee YY, Kim IS: Phospho-Stat3 expression and correlation with VEGF, p53, and $\mathrm{Bcl}-2$ in gastric carcinoma using tissue microarray. APMIS 2006;114:619-625.

4 Buettner R, Mora LB, Jove R: Activated STAT signaling in human tumors provides novel molecular targets for therapeutic intervention. Clin Cancer Res 2002;8:945-954.

5 Burke WM, Jin X, Lin HJ, Huang M, Liu R, Reynolds RK, Lin J: Inhibition of constitutively active Stat 3 suppresses growth of human ovarian and breast cancer cells. Oncogene 2001;20:7925-7934.

-6 Mora LB, Buettner R, Seigne J, Diaz J, Ahmad N, Garcia R, Bowman T, Falcone R, Fairclough R, Cantor A, Muro-Cacho C, Livingston S, Karras J, Pow-Sang J, Jove R: Constitutive activation of Stat 3 in human prostate tumors and cell lines: direct inhibition of Stat3 signaling induces apoptosis of prostate cancer cells. Cancer Res 2002;62:6659-6666.

-7 Duan Z, Foster R, Bell DA, Mahoney J, Wolak K, Vaidya A, Hampel C, Lee H, Seiden MV: Signal transducers and activators of transcription 3 pathway activation in drugresistant ovarian cancer. Clin Cancer Res 2006; 12:5055-5063.

8 Wang $\mathrm{H}$, Wang $\mathrm{H}$, Zhang W, Huang $\mathrm{HJ}$, Liao WS, Fuller GN: Analysis of the activation status of AKT, NF- $\kappa$ B, and Stat 3 in human diffuse gliomas. Lab Invest 2004;84:941-945.

$\checkmark 9$ Sano S, Chan KS, DiGiovanni J: Impact of Stat3 activation upon skin biology: a dichotomy of its role between homeostasis and diseases. J Dermatol Sci 2008;50:1-14.

10 Meinhold-Heerlein I, Bauerschlag D, Hilpert F, Dimitrov P, Sapinoso LM, Orlowska-Volk M, Bauknecht T, Park TW, Jonat W, Jacobsen A, Sehouli J, Luttges J, Krajewski M, Krajewski S, Reed JC, Arnold N, Hampton GM: Molecular and prognostic distinction between serous ovarian carcinomas of varying grade and malignant potential. Oncogene 2005;24: 1053-1065.

-11 Sheen-Chen SM, Huang CC, Tang RP, Chou FF, Eng HL: Prognostic value of signal transducers and activators of transcription 3 in

breast cancer. Cancer Epidemiol Biomarkers 22 Yan S, Zhou C, Zhang W, Zhang G, Zhao X, Prev 2008; 17:2286-2290.

-12 Nagpal JK, Mishra R, Das BR: Activation of Stat- 3 as one of the early events in tobacco chewing-mediated oral carcinogenesis. Cancer 2002;94:2393-2400.

13 Shah NG, Trivedi TI, Tankshali RA, Goswami JA, Jetly DH, Kobawala TP, Shukla SN, Shah PM, Verma RJ: Stat 3 expression in oral squamous cell carcinoma: association with clinicopathological parameters and survival. Int J Biol Markers 2006;21:175-183.

14 Crew KD, Neugut AI: Epidemiology of gastric cancer. World J Gastroenterol 2006;12: 354-362.

15 Kim JH, Kim MK, Lee HE, Cho SJ, Cho YJ, Lee BL, Lee HS, Nam SY, Lee JS, Kim WH: Constitutive phosphorylation of the FOXO1A transcription factor as a prognostic variable in gastric cancer. Mod Pathol 2007; 20:835-842.

16 Gong W, Wang L, Yao JC, Ajani JA, Wei D, Aldape KD, Xie K, Sawaya R, Huang S: Expression of activated signal transducer and activator of transcription 3 predicts expression of vascular endothelial growth factor and angiogenic phenotype of human gastric cancer. Clin Cancer Res 2005;11:1386-1393.

7 Kim DY, Cha ST, Ahn DH, Kang HY, Kwon CI, Ko KH, Hwang SG, Park PW, Rim KS, Hong SP: STAT3 expression in gastric cancer indicates a poor prognosis. J Gastroenterol Hepatol 2008;24:646-651.

18 Nam SY, Lee HS, Jung GA, Choi J, Cho SJ, Kim MK, Kim WH, Lee BL: AKT/PKB activation in gastric carcinomas correlates with clinicopathologic variables and prognosis. APMIS 2003;111:1105-1113.

19 Lee HS, Lee HK, Kim HS, Yang HK, Kim YI, Kim WH: MUC1, MUC2, MUC5AC, and MUC6 expressions in gastric carcinomas: their roles as prognostic indicators. Cancer 2001;92:1427-1434.

20 Ogunwobi OO, Beales IL: The anti-apoptotic and growth stimulatory actions of leptin in human colon cancer cells involves activation of JNK mitogen activated protein kinase, JAK2 and PI3 kinase/AKT. Int J Colorectal Dis 2007;22:401-409.

-21 Squarize CH, Castilho RM, Sriuranpong V, Pinto DS Jr, Gutkind JS: Cross-talk between the NF- $\kappa$ B and STAT3 signaling pathways in head and neck squamous cell carcinoma. Neoplasia 2006;8:733-746. Yang S, Wang Y, Lu N, Zhu H, Xu N: $\beta$ catenin/TCF pathway upregulates STAT3 expression in human esophageal squamous cell carcinoma. Cancer Lett 2008;271:85-97.

$\checkmark 23$ Lee KM, Lee DS, Yang JM, Ahn BM, Lee EH, Yoo JY, Kim YJ, Chung IS, Sun HS, Park DH: Effect of Helicobacter pylori on gastric epithelial cell kinetics and expression of apoptosis-related proteins in gastric carcinogenesis. Korean J Gastroenterol 2003;42:12-19.

24 Kacar F, Meteoğlu I, Yasa H, Levi E: Helicobacter pylori-induced changes in the gastric mucosa are associated with mitogen-activated protein kinase (MAPK) activation. Appl Immunohistochem Mol Morphol 2007;15: 224-228.

25 Iijima K, Koike T, Sekine H, Abe Y, Asanuma K, Ara N, Uno K, Imatani A, Ohara S, Shimosegawa T: Sustained epithelial proliferation in a functionally irreversible fundic mucosa after Helicobacter pylori eradication. J Gastroenterol 2009;44:47-55.

26 Lee KH, Lee HE, Cho SJ, Cho YJ, Lee HS, Kim JH, Nam SY, Chang MS, Kim WH, Lee BL: Immunohistochemical analysis of cell cycle-related molecules in gastric carcinoma: prognostic significance, correlation with clinicopathological parameters, proliferation and apoptosis. Pathobiology 2008; 75:364-372.

27 Kim YB, Han JY, Lee SH, Han HS, Kim TS, Chu YC, Hwang TS: Correlation between VEGF expression and angiogenesis in advanced gastric carcinoma. J Korean Can Assoc 1998;30:1061-1068.

28 Judd LM, Bredin K, Kalantzis A, Jenkins BJ, Ernst M, Giraud AS: STAT3 activation regulates growth, inflammation, and vascularization in a mouse model of gastric tumorigenesis. Gastroenterology 2006;131:1073-1085.

29 Stoeltzing O, McCarty MF, Wey JS, Fan F, Liu W, Belcheva A, Bucana CD, Semenza GL, Ellis LM: Role of hypoxia-inducible factor 11 in gastric cancer cell growth, angiogenesis and vessel maturation. J Natl Cancer Inst 2004;96:946-956.

-30 Cabuk D, Basaran G, Celikel C, Dane F, Yumuk PF, Iyikesici MS, Ekenel M, Turhal NS: Vascular endothelial growth factor, hypoxia-inducible factor 1 and CD34 expressions in early-stage gastric tumors: relationship with pathological factors and prognostic impact on survival. Oncology 2007;72:111-117. 